\title{
Ichthyofauna of Trairí river basin, Rio Grande do Norte state, northeastern Brazil: a century after the study of the naturalist Edwin Starks in the Papari lagoon
}

\author{
Lucas Silva de Medeiros ${ }^{1,2}$; Telton Pedro Anselmo Ramos ${ }^{1,3}$; Márcio Joaquim da Silva ${ }^{1,4}$; Roney Emanuel Costa de Paiva ${ }^{1,5}$; \\ Mateus Germano Souza Lira, ${ }^{1,6}$ Sergio Maia Queiroz Lima ${ }^{1,7}$ \\ 1 Universidade Federal do Rio Grande do Norte (UFRN), Centro de Biociências (CB), Departamento de Botânica e Zoologia (DBEZ), \\ Laboratório de Ictiologia Sistemática e Evolutiva. Natal, RN, Brasil. \\ 2 ORCID: http://orcid.org/0000-0001-9859-2128. E-mail: lucasmedeiros0@hotmail.com \\ 3 ORCID: http://orcid.org/0000-0002-3808-8701. E-mail: telton@gmail.com \\ ${ }^{4}$ ORCID: http://orcid.org/0000-0002-1477-474X. E-mail: silva.marcio.j@gmail.com \\ ${ }^{5}$ E-mail: roney.paiva@gmail.com \\ ${ }^{6}$ E-mail: mateuslupus@hotmail.com \\ 7 ORCID: http://orcid.org/0000-0001-9365-4879. E-mail: smaialima@gmail.com
}

\begin{abstract}
Fishes from the coastal basins of the Mid-Northeastern Caatinga ecoregion (MNCE) were first sampled by the Stanford expedition at the beginning of the $20^{\text {th }}$ century, and published by Edwin C. Starks in 1913 . This material included specimens from the Papary lake (= Papari lagoon) in the lower portion of the Trairi river basin, draining towards the eastern coast of Rio Grande do Norte State. In 1941, Henry Fowler provided a broad taxonomic study of the freshwater fishes from northeastern Brazil, including material from the Papari lagoon, besides describing four species assigned to this locality. However, these previous surveys focused only in the lower portion of the Trairi river basin and might be incomplete. Given this framework, the present study aimed at perform a wide ichthyofaunal inventory of Trairí river basin and compare with previously surveys performed in the regions. In 2013 and 2014, four expeditions along the whole basin, including the Papari lagoon itself, resulted in 28 species of fishes belonging to 17 families and seven orders. At Papari lagoon area 16 species were registered whereas 26 and 18 species were recorded by Starks and Fowler's studies, respectively. Considering all records, 50 species were documented in the basin with 14 (28\%) new records, including Serrapinnus potiguar, whose distribution was extended to the south. Two species described by Fowler, Pimelodella papariae and Pseudancistrus papariae, were not found in this study or in any fish collection, and are only known from their type-material. These two species can be naturally rare, locally extinct, or there were inaccuracies in their type-locality. However, species of these genera are only found in larger basins of the MNCE, which drains to the north, corroborating the latter assumption. Although not being a definitive list, the recent extensive fish surveys conducted in the MNCE's coastal basins are helping to elucidate species' geographic distribution and little knowing taxonomic issues.
\end{abstract}

Key-Words. Mid-Northeastern Caatinga Ecoregion; Freshwater fishes; Coastal basins; Semiarid.

\section{INTRODUCTION}

The Mid-Northeastern Caatinga Ecoregion (MNCE), composed by coastal basins fully or partially inserted in the semiarid, was a knowledge gap in the diversity of freshwater fishes until recently (Lévêque et al., 2008; Langeani et al., 2009; Lima et al., 2017). However, in the last decade many ichthyofaunal surveys and taxonomic studies were conducted in the ecoregion (GurgelLourenço et al., 2013; Novaes et al., 2013; Paiva et al., 2014; Silva et al., 2014, 2017; Botero et al., 2014; Lira et al., 2015; Ramos et al., 2013, 2016,
2017; Britzke et al., 2016; Rodrigues-Filho et al., 2016; Teixeira et al., 2017; Zawadzki et al., 2017; Costa et al., 2017; Lima et al., 2017). One of the first fish collections at the MNCE was undertaken by the Stanford Expedition in 1911 when a few drainages in Ceará and Rio Grande do Norte states were sampled (Starks, 1913). Among the sampled locations was the Papary lake (or 'Lago Papari'), located at the lower stretch of the Trairí river basin, draining to the eastern coast of Rio Grande do Norte State. Known since the $16^{\text {th }}$ century, its native name means "fish jump", emphasizing the abundance of fish (Ferreira, 2011). In the vicinity 
of the lagoon, in Nísia Floresta Municipality, there was established a fishermen community which was mentioned by Edwin Chapin Starks (1913) as responsible for the large fish collection at this locality.

Later, Fowler (1941) provided a taxonomic study on the fishes collected by Rodolpho von Ihering in many localities throughout northeastern Brazil in 1936 and 1937, including the Papari lagoon. In such study many species were described and four of them had their type-locality assigned to the Papari lagoon: Hypostomus papariae (Fowler), Pimelodella papariae (Fowler), Pseudancistrus papariae Fowler, and Psectrogaster saguiru Fowler (Fowler, 1941). However, previous surveys focused only in the lower portion of the Trairí river basin and might have been incomplete. Besides that, our surveys provide fresh specimens from an historically important type-locality that might allow important material for future taxonomic reviews and molecular systematic studies. Thus, the main purpose of the present study is to provide a reliable ichthyofaunal inventory of the Trairí river basin and compare the results with those obtained by Starks (1913) and Fowler (1941). Furthermore, some hypotheses concerning incongruences on the occurrence of some species described by Fowler were provided.

\section{MATERIAL AND METHODS}

\section{Study area}

The Trairí river basin has an approximate area of $2.900 \mathrm{~km}^{2}$, of which $99.63 \%$ are inserted in Rio Grande do Norte State (RN) and a small fraction of its upper portion in Paraíba State (ANA/SGI, 2014) (Fig. 1). It is located in the northeastern portion of the MNCE (Fig. 1), which is characterized by temporary rivers and lower species richness in comparison to the adjacent ecoregions, notwithstanding its high endemism (Albert et al., 2011). The main course of the Trairí river emerges at Serra do Doutor (in Campo Redondo and Coronel Ezequiel municipalities, in RN) and flows to Guaraíras lagoon between Tibau do Sul and Senador Georgino Avelino municipalities, also in RN (IBGE, 1990). About $88 \%$ of the basin lies within the Caatinga and the remaining in the Atlantic Forest (ANA/ $\mathrm{SGl}, 2014)$. Rains are more abundant in the coast, varying from 1,300 $\mathrm{mm}$ annually at the estuary to $500 \mathrm{~mm}$ in Santa Cruz municipality ("Agreste" portion of RN), and $700 \mathrm{~mm}$ close to the river's headwaters (SERHID, 2001).

\section{Sampling design}

Four expeditions were conducted between October 2013 and August 2014 during dry and rainy seasons, consisting of 27 sampling locations (Fig. 1 and Table 1) from the upper stretch to the lower portion of Trairí river basin. The sampling sites marked with an asterisk in Table 1 were at the border of the Papari lagoon.

Samplings were done during the day and, occasionally at night, under collection permit 30532-1/2011
Table 1. Sampled locations and municipalities in Trairi river coastal basin. All sites are within Rio Grande do Norte state, Brazil. * Sampling sites at the Papari lagoon.

\begin{tabular}{|c|c|c|}
\hline Locality & $\begin{array}{c}\text { Elevation } \\
(\mathrm{m})\end{array}$ & $\begin{array}{l}\text { Geographic } \\
\text { Coordinates }\end{array}$ \\
\hline 1. Unnamed stream, Vera Cruz & $366 m$ & $\begin{array}{l}05^{\circ} 50^{\prime} 32.3^{\prime \prime} \mathrm{S} \\
36^{\circ} 12^{\prime} 07.5^{\prime \prime} \mathrm{W}\end{array}$ \\
\hline 2. Barro Branco reservoir, Coronel Ezequiel & $487 \mathrm{~m}$ & $\begin{array}{l}06^{\circ} 22^{\prime} 02.6^{\prime \prime} \mathrm{S} \\
36^{\circ} 14^{\prime} 33.4^{\prime \prime} \mathrm{W}\end{array}$ \\
\hline 3. Unnamed reservoir in Coronel Ezequiel & $362 m$ & $\begin{array}{l}06^{\circ} 19^{\prime} 22.7^{\prime \prime} \mathrm{S} \\
36^{\circ} 11^{\prime} 45.6^{\prime \prime} \mathrm{W}\end{array}$ \\
\hline 4. Trairí reservoir, Tangará & $179 \mathrm{~m}$ & $\begin{array}{l}06^{\circ} 15^{\prime} 11.7^{\prime \prime} \mathrm{S} \\
35^{\circ} 49^{\prime} 40.2^{\prime \prime} \mathrm{W}\end{array}$ \\
\hline 5. Mãe D'Água reservoir, Campo Redondo & $471 \mathrm{~m}$ & $\begin{array}{l}06^{\circ} 14^{\prime} 34.4^{\prime \prime} \mathrm{S} \\
36^{\circ} 11^{\prime} 27.7^{\prime \prime} \mathrm{W}\end{array}$ \\
\hline 6. Novo reservoir, Santa Cruz & $238 \mathrm{~m}$ & $\begin{array}{l}06^{\circ} 13^{\prime} 33.4^{\prime \prime} \mathrm{S} \\
36^{\circ} 01^{\prime} 38.3^{\prime \prime} \mathrm{W}\end{array}$ \\
\hline 7. Unnamed stream, Lagoa de Pedra & $120 \mathrm{~m}$ & $\begin{array}{l}06^{\circ} 12^{\prime} 34.9^{\prime \prime} \mathrm{S} \\
35^{\circ} 23^{\prime} 51.7^{\prime \prime} \mathrm{W}\end{array}$ \\
\hline 8. Tiquinho Miranda dam, Boa Saúde & $90 \mathrm{~m}$ & $\begin{array}{l}06^{\circ} 09^{\prime} 43.1^{\prime \prime} \mathrm{S} \\
35^{\circ} 35^{\prime} 58.7^{\prime \prime} \mathrm{W}\end{array}$ \\
\hline 9. Unnamed stream, Brejinho & $66 \mathrm{~m}$ & $\begin{array}{l}06^{\circ} 09^{\prime} 39.6^{\prime \prime} \mathrm{S} \\
35^{\circ} 19^{\prime} 34.1^{\prime \prime} \mathrm{W}\end{array}$ \\
\hline 10. Unnamed stream, Brejinho & $34 \mathrm{~m}$ & $\begin{array}{l}06^{\circ} 08^{\prime} 40.5^{\prime \prime} \mathrm{S} \\
35^{\circ} 18^{\prime} 43.7^{\prime \prime} \mathrm{W}\end{array}$ \\
\hline 11. Papari lagoon, Nísia Floresta* & $20 \mathrm{~m}$ & $\begin{array}{l}06^{\circ} 06^{\prime} 44.3^{\prime \prime} \mathrm{S} \\
35^{\circ} 11^{\prime} 15.6^{\prime \prime} \mathrm{W}\end{array}$ \\
\hline 12. Unnamed marginal lagoon, Lagoa Salgada & $119 m$ & $\begin{array}{l}06^{\circ} 06^{\prime} 55.9^{\prime \prime} \mathrm{S} \\
35^{\circ} 31^{\prime} 16.9^{\prime \prime} \mathrm{W}\end{array}$ \\
\hline 13. Araraí river, São José de Mipibu & $6 \mathrm{~m}$ & $\begin{array}{l}06^{\circ} 06^{\prime} 39.7^{\prime \prime} \mathrm{S} \\
35^{\circ} 14^{\prime} 02.4^{\prime \prime} \mathrm{W}\end{array}$ \\
\hline 14. Unnamed stream near Papari lagoon, Nísia Floresta & $19 \mathrm{~m}$ & $\begin{array}{l}06^{\circ} 06^{\prime} 39.5^{\prime \prime} \mathrm{S} \\
35^{\circ} 12^{\prime} 07.7^{\prime \prime} \mathrm{W}\end{array}$ \\
\hline 15. Unnamed stream, Nísia Floresta* & $12 \mathrm{~m}$ & $\begin{array}{l}06^{\circ} 06^{\prime} 36.7^{\prime \prime} \mathrm{S} \\
35^{\circ} 12^{\prime} 10.7^{\prime \prime} \mathrm{W}\end{array}$ \\
\hline 16. Corró Novo river, São José de Mipibu & $35 \mathrm{~m}$ & $\begin{array}{l}06^{\circ} 06^{\prime} 26.3^{\prime \prime} \mathrm{S} \\
35^{\circ} 18^{\prime} 03.4^{\prime \prime} \mathrm{W}\end{array}$ \\
\hline 17. Unnamed stream, São José de Mipibu & $15 \mathrm{~m}$ & $\begin{array}{l}06^{\circ} 06^{\prime} 24.3^{\prime \prime} \mathrm{S} \\
35^{\circ} 16^{\prime} 05.0^{\prime \prime} \mathrm{W}\end{array}$ \\
\hline 18. Edge North of Papari lagoon, Nísia Floresta* & $10 \mathrm{~m}$ & $\begin{array}{l}06^{\circ} 06^{\prime} 13.9^{\prime \prime} \mathrm{S} \\
35^{\circ} 11^{\prime} 27.9^{\prime \prime} \mathrm{W}\end{array}$ \\
\hline 19. Papari lagoon, Nísia Floresta & $10 \mathrm{~m}$ & $\begin{array}{l}06^{\circ} 07^{\prime} 14,7^{\prime \prime} \mathrm{S} \\
35^{\circ} 10^{\prime} 00,3^{\prime \prime} \mathrm{W}\end{array}$ \\
\hline 20. Trairí river, São José de Mipibu & $13 \mathrm{~m}$ & $\begin{array}{l}06^{\circ} 06^{\prime} 03.5^{\prime \prime} \mathrm{S} \\
35^{\circ} 14^{\prime} 02.0^{\prime \prime} \mathrm{W}\end{array}$ \\
\hline 21. Unnamed stream, Nísia Floresta & $17 \mathrm{~m}$ & $\begin{array}{l}06^{\circ} 05^{\prime} 39.5^{\prime \prime} \mathrm{S} \\
35^{\circ} 11^{\prime} 58.5^{\prime \prime} \mathrm{W}\end{array}$ \\
\hline 22. Trairí river, Lagoa Salgada & $41 \mathrm{~m}$ & $\begin{array}{l}06^{\circ} 05^{\prime} 08.2^{\prime \prime} \mathrm{S} \\
35^{\circ} 22^{\prime} 59.4^{\prime \prime} \mathrm{W}\end{array}$ \\
\hline 23. Unnamed tributary of Trairí river, São José do Mipibú & $10 \mathrm{~m}$ & $\begin{array}{l}06^{\circ} 04^{\prime} 55.4^{\prime \prime} \mathrm{S} \\
35^{\circ} 13^{\prime} 45.9^{\prime \prime} \mathrm{W}\end{array}$ \\
\hline 24. Unnamed stream, Monte Alegre & $44 \mathrm{~m}$ & $\begin{array}{l}06^{\circ} 03^{\prime} 47.4^{\prime \prime} \mathrm{S} \\
35^{\circ} 18^{\prime} 41.6^{\prime \prime} \mathrm{W}\end{array}$ \\
\hline 25. Unnamed stream, Monte Alegre & $37 \mathrm{~m}$ & $\begin{array}{l}06^{\circ} 03^{\prime} 35.7^{\prime \prime} \mathrm{S} \\
35^{\circ} 21^{\prime} 52.8^{\prime \prime} \mathrm{W}\end{array}$ \\
\hline 26. Vera Cruz stream, Vera Cruz & $70 \mathrm{~m}$ & $\begin{array}{l}06^{\circ} 03^{\prime} 02.4^{\prime \prime} \text {; } \\
35^{\circ} 23^{\prime} 25.7^{\prime \prime} \mathrm{W}\end{array}$ \\
\hline 27. Arenã stream, Vera Cruz & $41 \mathrm{~m}$ & $\begin{array}{l}06^{\circ} 03^{\prime} 03.7^{\prime \prime} \mathrm{S} ; \\
35^{\circ} 20^{\prime} 57.4^{\prime \prime} \mathrm{W}\end{array}$ \\
\hline
\end{tabular}

from Instituto Chico Mendes de Conservação da Biodiversidade/Sistema de Autorização e Informação em Biodiversidade - ICMBio/SISBIO) and applying the AquaRAP methodology (Rapid Assessment Protocol in Aquatic Systems) proposed by Alonso \& Willink (2011). 

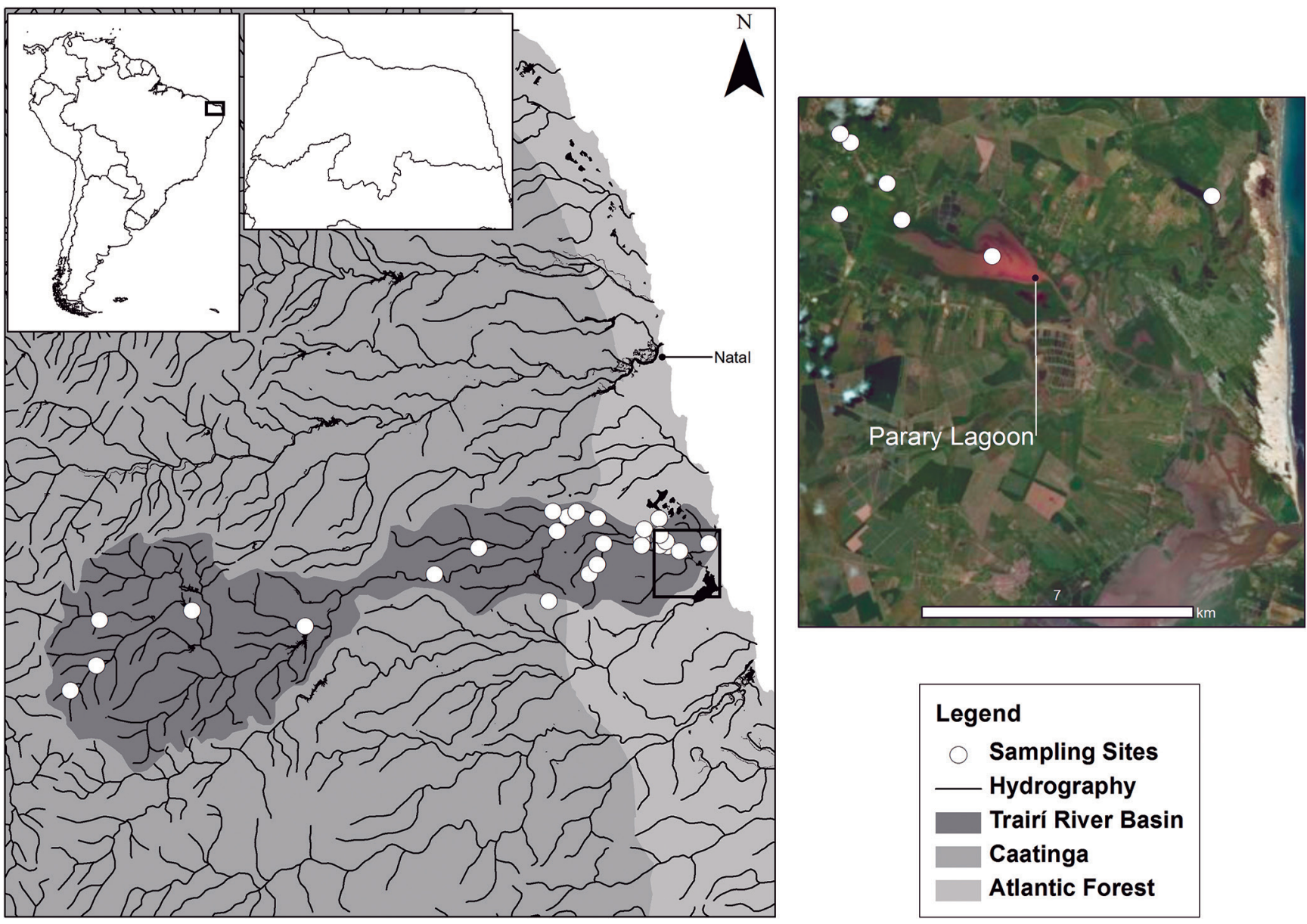

Figure 1. Map of sampling sites of the ichthyofaunal survey in Trairí river coastal basin, Rio Grande do Norte State, northeastern Brazil.

Fishes were collected using active sampling gear, such as trawl $(4.1 \times 2.2 \mathrm{~m}$ and $5.0 \mathrm{~mm})$, sieve $(0.8 \mathrm{~m} \times 0.5 \mathrm{~mm})$, cast net $(1.5 \mathrm{~m} \times 12.0 \mathrm{~mm})$, and gill nets as passive sampling gear to embody the highest number of microhabitats and reduce method selectivity (Uieda \& Castro, 1999; Sabino, 1999). Casting nets were also used in the middle of the Papari lagoon with the help of a local fisherman boat.

After collected, specimens were anesthetized in a $10 \%$ alcoholic eugenol solution $(10 \mathrm{~mL}$ of clove oil; $90 \mathrm{~mL}$ of ethyl alcohol) (Lucena et al., 2013), then fixed in 10\% formaldehyde and posteriorly transferred to a $70 \%$ ethanol solution (Malabarba \& Reis, 1987). Specimens' identification was done to the lower taxonomic level based on specialized literature (Britski et al., 1984; Kullander, 1983; Marceniuk, 2005; Ploeg, 1991; Figueiredo \& Menezes, 1980 and Carpenter, 2002), or specialists' support. The systematic classification and nomenclature of valid species followed Eschmeyer et al. (2017). Specimens were deposited at the ichthyological collection of the Universidade Federal do Rio Grande do Norte (UFRN).

Recently collected data were compared to those recorded by Starks (1913) and Fowler (1941) (Table 2). An updated identification of this material was checked in the online database from the Stanford University (SU) at California Academy of Science (http://researcharchive. calacademy.org/research/lchthyology/collection/index.asp), and the Academy of Natural Science of Drexel
University (ANSP). The species collected by Starks and Fowler refers only to the Papari lagoon, while those collected throughout this survey in the lagoon are marked with an asterisk (Table 2).

Ecophysiological classification of salinity tolerance followed Myers (1949). The Brazilian list of endangered species (MMA, 2014) was used to discuss the conservation status of each species. Endemism of freshwater fishes, defined by occurrence in the MNCE, followed Rosa et al. (2003), Buckup et al. (2007), and Lima et al. (2017). Lastly, the list of exotic species followed Leão et al. (2011).

\section{RESULTS}

A total of 28 species belonging to 25 genera, 17 families, and six orders were recorded in our surveys. Primary freshwater species were predominant (16 spp., 57.1\%), followed by secondary (7 spp., 25\%) and peripheral (5 spp., 17.9\%) (Table 2). The order Characiformes was the most representative with six families, nine genera, and 12 species (42.8\%), followed by Siluriformes with five families, five genera, and five species (17.8\%), and Cichliformes with one family, four genera and four species (14.3\%). The order Synbranchiformes was represented by a single species.

Sixteen species $(57.1 \%)$ were collected in the Papari lagoon area, being nine primary freshwater (Astyanax 
Table 2. Systematic list of fish species collected in Trairí river basin, Rio Grande do Norte. Material collected by Starks (1913) and Fowler (1941) from Papari lagoon. FPE: peripheral freshwater; FPR: primary freshwater; FSE: secondary freshwater; MAR: marine. E: endemic species from the Mid-Northeastern Caatinga Ecoregion; EX: exotic species; *Species collected at the Papari lagoon during this study. (V))Vulnerable species, and ${ }^{(S)}$ Species inquirenda. ANSP: The Academy of Natural Sciences of Drexel University; SU: Ichthyological collection of Stanford University at California Academy of Sciences; UFRN: Universidade Federal do Rio Grande do Norte.

\begin{tabular}{|c|c|c|c|c|c|c|}
\hline ORDER/Family/Species & Ecophysiology & Starks 1913 & Fowler 1941 & This study & Endemism & Voucher \\
\hline \multicolumn{7}{|l|}{ ELOPIFORMES (2) } \\
\hline \multicolumn{7}{|l|}{ Elopidae (1) } \\
\hline Elops saurus Linnaeus, 1766 & MAR & $x$ & & & & SU 22185 \\
\hline \multicolumn{7}{|l|}{ Megalopidae (1) } \\
\hline Megalops atlanticus Valenciennes, $1847^{(\mathrm{VU})}$ & MAR & $\mathrm{X}$ & & & & SU 22175 \\
\hline \multicolumn{7}{|l|}{ CLUPEIFORMES (1) } \\
\hline \multicolumn{7}{|l|}{ Engraulidae (1) } \\
\hline Anchovia clupeoides (Swainson, 1839) & FPE & $\mathrm{X}$ & & & & SU 22095 \\
\hline \multicolumn{7}{|l|}{ CHARACIFORMES (17) } \\
\hline \multicolumn{7}{|l|}{ Crenuchidae (1) } \\
\hline Characidium bimaculatum Fowler, 1941 & FPR & & & $X^{*}$ & & UFRN 2361 \\
\hline \multicolumn{7}{|l|}{ Erythrinidae (2) } \\
\hline Erythrinus erythrinus (Bloch \& Schneider, 1801) & FPR & & & $X^{*}$ & & UFRN 2322 \\
\hline Hoplias malabaricus (Bloch, 1794) & FPR & $\mathrm{X}$ & $x$ & $X^{*}$ & & UFRN 2396 ANSP 95881 \\
\hline \multicolumn{7}{|l|}{ Serrasalmidae (3) } \\
\hline Metynnis lippincottianus (Cope, 1870) & FPR & $x$ & & & & SU 22183 \\
\hline Pygocentrus nattereri Kner, 1858 & FPR & & $x$ & & & ANSP 87812 \\
\hline Serrasalmus rhombeus (Linnaeus, 1766) & FPR & & $\mathrm{X}$ & & & ANSP 88500 \\
\hline \multicolumn{7}{|l|}{ Anostomidae (1) } \\
\hline Leporinus piau Fowler, 1941 & FPR & & $\mathrm{X}$ & $\mathrm{X}$ & & ANSP 69495, UFRN 1930 \\
\hline \multicolumn{7}{|l|}{ Curimatidae (2) } \\
\hline Psectrogaster saguiru (Fowler, 1941) & FPR & & $\mathrm{X}$ & & $\mathbf{E}$ & ANSP 69461 \\
\hline Steindachnerina notonota (Miranda Ribeiro, 1937) & FPR & $\mathrm{X}$ & $x$ & $X^{*}$ & & SU 22458, ANSP 69453, UFRN 2339 \\
\hline \multicolumn{7}{|l|}{ Prochilodontidae (1) } \\
\hline Prochilodus brevis Steindachner, 1875 & FPR & & $x$ & $X^{*}$ & $\mathbf{E}$ & UFRN 2342, ANSP 96051 \\
\hline \multicolumn{7}{|l|}{ Triportheidae (1) } \\
\hline Triportheus signatus (Garman, 1890) & FPR & & $\mathrm{X}$ & & $\mathbf{E}$ & ANSP 84094 \\
\hline \multicolumn{7}{|l|}{ Characidae (6) } \\
\hline Astyanax aff. bimaculatus (Linnaeus, 1758) & FPR & $\mathrm{X}$ & $\mathrm{X}$ & $X^{*}$ & & SU 22176, ANSP 81920, UFRN 2360 \\
\hline Astyanax aff. fasciatus (Cuvier, 1819) & FPR & & & $x$ & & UFRN 2369 \\
\hline Hemigrammus marginatus Ellis, 1911 & FPR & & & $X$ & & UFRN 2341 \\
\hline Serrapinnus heterodon (Eigenmann, 1915) & FPR & & & $X^{*}$ & & UFRN 2373 \\
\hline Serrapinnus piaba (Lütken, 1875) & FPR & & & $X^{*}$ & & UFRN 2362 \\
\hline Serrapinnus potiguar Jerep \& Malabarba 2014 & FPR & & & $X$ & $\mathbf{E}$ & UFRN 3429 \\
\hline \multicolumn{7}{|l|}{ SILURIFORMES (7) } \\
\hline \multicolumn{7}{|l|}{ Auchenipteridae (1) } \\
\hline Trachelyopterus galeatus (Linnaeus, 1766) & FPR & & $x$ & $X$ & & ANSP 96050, UFRN 3430 \\
\hline \multicolumn{7}{|l|}{ Heptapteridae (2) } \\
\hline Pimelodella papariae (Fowler 1941)(s) & FPR & & $x$ & & $\mathbf{E}$ & ANSP 69387 \\
\hline Rhamdia quelen (Quoy \& Gaimard, 1824) & FPR & & & $X$ & & UFRN 3257 \\
\hline Ariidae (1) & & & & & & \\
\hline Bagre marinus (Mitchill, 1815) & FPE & & & $X^{*}$ & & UFRN 2319 \\
\hline Callichthyidae (1) & & & & & & \\
\hline Megalechis thoracata (Valenciennes, 1840) & FPR & $x$ & & $X^{*}$ & & SU 22163, UFRN 2363 \\
\hline Loricariidae (2) & & & & & & \\
\hline Hypostomus papariae (Fowler, 1941)(SI) & FPR & & $\mathrm{X}$ & $X$ & $\mathbf{E}$ & UFRN 2399, ANSP 69398 \\
\hline Pseudancistrus papariae Fowler, $1941^{(\mathrm{SI})}$ & FPR & & $\mathrm{X}$ & & $\mathbf{E}$ & ANSP 69442 \\
\hline GYMNOTIFORMES (1) & & & & & & \\
\hline Gymnotidae (1) & & & & & & \\
\hline Gymnotus carapo Linnaeus, 1758 & FPR & $x$ & & & & SU 22475 \\
\hline GOBIIFORMES (3) & & & & & & \\
\hline Eleotridae (2) & & & & & & \\
\hline Eleotris pisonis (Gmelin, 1789) & FPE & $x$ & & $X^{*}$ & & SU 22208, UFRN 2327 \\
\hline Dormitator maculatus (Bloch, 1792) & FPE & $x$ & & $x$ & & SU 22478, UFRN 3313 \\
\hline Gobiidae (1) & & & & & & \\
\hline Awaous tajasica Lichtenstein, 1822 & FPE & $X$ & & & & SU 22154 \\
\hline
\end{tabular}




\begin{tabular}{|c|c|c|c|c|c|c|}
\hline ORDER/Family/Species & Ecophysiology & Starks 1913 & Fowler 1941 & This study & Endemism & Voucher \\
\hline \multicolumn{7}{|l|}{ SYNBRANCHIFORMES (1) } \\
\hline \multicolumn{7}{|l|}{ Synbranchidae (1) } \\
\hline Synbranchus aff. marmoratus Bloch, 1795 & FSE & $\mathrm{x}$ & $\mathrm{x}$ & $\mathrm{x}$ & & SU 22202, UFRN 2347 \\
\hline \multicolumn{7}{|l|}{ PLEURONECTIFORMES (1) } \\
\hline \multicolumn{7}{|l|}{ Achiridae (1) } \\
\hline Achirus achirus (Linnaeus, 1758) & MAR & $x$ & $x$ & & & SU 22127, ASNP 73985 \\
\hline \multicolumn{7}{|l|}{ CICHLIFORMES (4) } \\
\hline \multicolumn{7}{|l|}{ Cichlidae (4) } \\
\hline Cichlasoma orientale Kullander, 1983 & FSE & $x$ & $x$ & $X^{*}$ & & SU 22449, ANSP 84124, UFRN 2358 \\
\hline Crenicichla brasiliensis (Bloch, 1792) & FSE & $x$ & $x$ & $X^{*}$ & & SU 22476, ANSP 96047, UFRN 2308 \\
\hline Geophagus brasiliensis (Quoy \& Gaimard, 1824) & FSE & & & $x$ & & UFRN 2283 \\
\hline Oreochromis niloticus (Linnaeus, 1758)(Ex) & FSE & & & $X^{*}$ & & UFRN 2305 \\
\hline \multicolumn{7}{|l|}{ ATHERINIFORMES (1) } \\
\hline \multicolumn{7}{|l|}{ Atherinopsidae (1) } \\
\hline Atherinella brasiliensis (Quoy \& Gaimard, 1825) & FPE & $x$ & & & & SU 22101 \\
\hline \multicolumn{7}{|l|}{ CYPRINODONTIFORMES (2) } \\
\hline \multicolumn{7}{|l|}{ Poecilidae (2) } \\
\hline Poecilia reticulata Peters, $1859^{(\mathrm{EX})}$ & FSE & & & $x$ & & UFRN 2359 \\
\hline Poecilia vivipara Bloch \& Schneider, 1801 & FSE & & & $X^{*}$ & & UFRN 2357 \\
\hline \multicolumn{7}{|l|}{ BELONIFORMES (1) } \\
\hline \multicolumn{7}{|l|}{ Belonidae (1) } \\
\hline Strongylura marina (Walbaum, 1792) & FPE & $x$ & & & & SU 64920 \\
\hline \multicolumn{7}{|l|}{ MUGILIFORMES (1) } \\
\hline \multicolumn{7}{|l|}{ Mugilidae (1) } \\
\hline Mugil liza Valenciennes, 1836 & MAR & $x$ & $x$ & & & SU 13241 \\
\hline \multicolumn{7}{|l|}{ PERCIFORMES (8) } \\
\hline \multicolumn{7}{|l|}{ Centropomidae (2) } \\
\hline Centropomus mexicanus (Bocourt, 1868) & FPE & $x$ & & & & SU 22103 \\
\hline Centropomus undecimalis (Bloch, 1792) & FPE & $x$ & & $X^{*}$ & & SU 22115, UFRN 2320 \\
\hline \multicolumn{7}{|l|}{ Gerreidae (5) } \\
\hline Diapterus auratus (Ranzani, 1842) & FPE & $x$ & & & & SU 22140 \\
\hline Diapterus rhombeus (Cuvier 1829) & FPE & $x$ & & & & SU 22091 \\
\hline Eucinostomus gula (Quoy \& Gaimard, 1824) & MAR & $x$ & & & & SU 22143 \\
\hline Eucinostomus jonesii (Günther 1879) & MAR & $x$ & & & & \\
\hline Eugerres brasilianus (Cuvier, 1830) & MAR & $x$ & & & & SU 22144 \\
\hline \multicolumn{7}{|l|}{ Sciaenidae (1) } \\
\hline Plagioscion squamosissimus (Heckel, 1840)(Ex) & FPE & & & $x$ & & UFRN 2307 \\
\hline Total/excluding introduced species (50/47) & & 26 & 18 & 28 & & \\
\hline
\end{tabular}

aff. bimaculatus, Characidium bimaculatum, Erythrinus erythrinus, Hoplias malabaricus, Megalechis thoracata, Prochilodus brevis, Serrapinnus heterodon, S. piaba, and Steindachnerina notonota), four secondary (Cichlasoma orientale, Crenicichla brasiliensis, Poecilia vivipara and Oreochromis niloticus), and three peripheral (Bagre marinus, Centropomus undecimalis and Eleotris pisonis) (Table 2).

Of these 28 species herein registered (Table 2), 14 had already been recorded in previously studies (i.e., Starks, 1913; Fowler, 1941). Therefore, 14 species (Astyanax aff. fasciatus, Bagre marinus, Characidium bimaculatum, Erythrinus erythrinus, Geophagus brasiliensis, Hemigrammus marginatus, Oreochromis niloticus, Plagioscion squamosissimus, Poecilia reticulata, $P$. vivipara, Rhamdia quelen, Serrapinnus heterodon, S. piaba and S. potiguar), most of which are freshwater, are new records for the basin, raising its richness to 50 species. Besides, three of them were introduced: the Nile tilapia (Oreochromis niloticus), the silver croaker (Plagioscion squamosissimus), and the guppy (Poecilia reticulata).
No threatened species was recently collected; however, Starks recorded Megalops atlanticus Valenciennes, 1847, which is evaluated as 'vulnerable' (MMA, 2014).

\section{DISCUSSION}

Starks described the Papari lagoon as a large, shallow, and muddy estuarine water body with abundant superficial vegetation, which made it laborious to trawl fishes (Starks, 1913). Being aided by local fishermen, he intensively sampled the lagoon during several days, collecting 26 species, most of which were estuarine (Table 2) (six primary freshwater fish species, three secondary, ten peripheral, and seven marine) (Starks, 1913). In 1936, von Ihering collected 18 species at the same locality (Table 2 ) (13 primary freshwater, three secondary, and two marine), being eight previously recorded by Starks (Achirus achirus, Astyanax aff. bimaculatus, Cichlasoma orientale, Crenicichla brasiliensis, Hoplias malabaricus, Mugil liza, Steindachnerina notonota, and Synbranchus aff. bimac- 
ulatus), and ten were new records (Hypostomus papariae, Leporinus piau, Pimelodella papariae, Prochilodus brevis, Psectrogaster saguiru, Pseudancistrus papariae, Pygocentrus nattereri, Serrasalmus rhombeus, Triportheus signatus, and Trachelyopterus galeatus) (Fowler, 1941). These studies together accounted for 36 fish species in the Papari lagoon (Table 2). The updated taxonomic list of the fish species herein provided allowed a comparison between these previous studies in the Papari lagoon.

Considering the records of Starks (1913), Fowler (1941), and those of the recent surveys, 50 species were documented in the Trairí river basin. Among the 14 new records, it is remarkable the occurrence of Serrapinnus potiguar, which was only known from the Ceará-Mirim river basin (Jerep \& Malabarba, 2014), located about $55 \mathrm{~km}$ to the north of Trairí river basin, expanding southward the distribution of this recently described species. However, since the Papari lagoon is situated at the estuarine portion of Trairí river basin and it is directly influenced by tides, as reported by Jenkins \& Branner (1913), the records of Gymnotus carapo, Hypostomus papariae, Metynnis lippincottianus, Pimelodella papariae, Psectrogaster saguiru, Pseudancistrus papariae, Pygocentrus nattereri, and Serrasalmus rhombeus are dubious, and might have been captured upstream, as they are characterized as freshwater species and have low salinity tolerance (Myers, 1949).

Starks (1913) and Fowler (1941) did not register any introduced species in the Papari lagoon, suggesting a scenario of environmental degradation over the last decades, since in recent samplings three introduced species were recorded: two from fish farming or aquaculture (Oreochromis niloticus and Plagioscion squamosissimus), and one from aquarium trade (Poecilia reticulata) (Leão et al., 2011). In addition to the introduction of exotic species of fish, the lagoon has been suffering from environmental impacts due to intense development of shrimp farming in Rio Grande do Norte State (Santos \& Coelho, 2002). Some stretches have been greatly modified at the lower portion of Trairí river basin as a result of the removal of riparian vegetation and riverbed sand for building shrimp farms, contributing for the lagoon's silting. Besides, waste (antibiotics and organic matter) coming from those farms are dumped into the Papari lagoon without any prior treatment (Santos, 2005). According to Santos (2005), the small height of dikes has been contributing for the overflow of farms in the rainy seasons and for the invasion of the exotic shrimp species Litopenaeus vannamei (Boone) into the Papari-Guaraíras lagoon complex.

Fowler (1941) described many species from several type localities along the Brazilian northeast. At the Papari lagoon he described four species of which three are catfishes (Hypostomus papariae, Pimelodella papariae, and Pseudancistrus papariae) and one is a characin (Psectrogaster saguiru). However, except the latter, Fowler's descriptions do not exhibit any diagnostic characters that allow their differentiation from congeners, including those of the same study. There have been some doubts regarding the taxonomic validity and geographic distribution of the species Pseudancistrus papariae and
Pimelodella papariae once they have not been recorded in coastal basins that flow to the eastern coast of the MNCE and are only known from their type-series (Lima et al., 2017).

Possible locality mislabeling or erroneous identifications of lots assigned to the Papari lagoon by Fowler (1941) are realistic possibilities, as already mentioned by Vari (1989) and Ramos et al. (2017). These authors noticed that the localities attributed to Psectrogaster saguiru (Lago Papary, Rio Grande do Norte) and Hypostomus eptingi (Fortaleza, Ceará) belong to the basins of the Jaguaribe and Parnaíba rivers, respectively. This could also have happened to further fishes of the Papari lagoon, based on the same kind of observation: the absence of some species (e.g., Pimelodella papariae and Pseudancistrus papariae) despite recent and previous surveys in the Trairí river basin, and the presence of some relatively largesized species (e.g., Psectrogaster saguiru, Pygocentrus nattereri, Serrasalmus rhombeus, and Triportheus signatus) that are more common in the larger basins of the MNCE. These factors also contribute to questionings concerning the actual provenance of such species.

In northeastern Brazil, specimens of Pseudancistrus are only known from the two largest basins of the MNCE, which drain to the north, Jaguaribe and Piranhas-Açu rivers, and are usually identified as $P$. genisetiger (Lima et al., 2017). Between 1936 and 1937, von Ihering and his team collected in many drainages in northeastern Brazil, including these MNCE's large basins (Fowler, 1941); therefore, the material assigned as Pseudancistrus papariae might have come from these drainages. Starks (1913) also did not record any specimen of this genus in Papari lagoon or in any sampling site. Due to the virtual absence of representatives of the genus in Trairí river basin and in other MNCE's eastern coastal drainages, Lima et al. (2017) suggested that it might have been some location mislabeling in the lots supposedly assigned to the Papari lagoon.

Fowler (1941) also described eight species currently allocated in the genus Pimelodella in northeastern Brazil, besides recognizing $P$. gracilis (Valenciennes). Six of those are from the MNCE ( $P$. dorseyi, $P$. enochi, $P$. gracilis, $P$. papariae, $P$. witmeri, and $P$. wolfi); however, these descriptions do not establish a clear distinction among the proposed species, sometimes belonging to the same drainage (Slobodian, 2018). The same seems to apply to Fowler's Hypostomus species, with $H$. papariae being difficult to be distinguished from $H$. pusarum Starks based on the original description. Meanwhile, H. papariae, Pimelodella papariae, and Pseudancistrus papariae were listed as species inquirendae by Lima et al. (2017).

Taxonomic uncertainties caused by brief descriptions, locality mislabeling in Fowler's study (1941), and complex nomenclature emphasize the need of taxonomic revisions of the genera Hypostomus, Pseudancistrus, and Pimelodella from northeastern Brazil basins. This is paramount to determine their taxonomic validity, including some species supposedly described from the Papari lagoon, in the Trairí river basin. Although not definitive, the extensive surveys of freshwater fish species from the 
MNCE's coastal basins are providing more knowledge to solve the taxonomic problems. It also helps in gathering fresh material for morphological and molecular studies, as well as to assess the anthropogenic impacts, mainly in drainages with historical inventories and which are the type locality of some species.

\section{ACKNOWLEDGEMENTS}

The authors are thankful to Dr. Fernando Carvalho (UFMS) for identifying specimens of the genus Hemigrammus, and to Waldir Berbel-Filho, Janaína Gomes, and students who took the discipline of Ichthyology 2013.2 at UFRN for helping in fieldwork activities. TPAR received postdoctoral fellowship from FAPERN/CNPq (350674/2012-4), LSM and MGSL scientific initiation scholarship from PROPESQ, RECP Master's scholarship from PRH-ANP (Programa de Recursos Humanos da Agência Nacional de Petróleo, Gás Natural e Biocombustíveis, proc. 486100097362013). This study was financed in part by the Coordenação de Aperfeiçoamento de Pessoal de Nível Superior - Brasil (CAPES) - Finance Code 001.

\section{REFERENCES}

Agência Nacional de Águas (ANA)/Superintendência de Gestão da Informação (SGI). 2014. Unidades Hidrográficas Estaduais. Available at: http:// metadados.ana.gov.br/geonetwork/srv/pt/main.home. Access in: 15/09/2015.

Albert, J.S.; Petry, P. \& Reis, R.E. 2011. Major biogeographic and phylogenetic patterns. In: Albert, J.S. \& Reis, R.E. (Eds.). Historical biogeography of neotropical freshwater fishes. Berkeley, University of California Press. p. 21-58.

Alonso, L.E. \& Willink, P. 2011. History and overview of AquaRAP. In: Alonso, L.E.; Deichmann, J.L.; Mckenna, S.A.; Naskrecki, P. \& Richards, S.J. (Eds.). Biodiversity exploration for conservation - the first 20 years of the Rapid Assessment Program. Arlington, Conservation International. p. 80-90.

Botero, J.I.S.; Garcez, D.S.; Cascon, P.; Lima, S.M.Q.; Brito, L.B.M. \& Roberto, I.J. 2014. Anfíbios e peixes do Parque Nacional de Ubajara e entorno. Fortaleza, UFC/LABOMAR/NAVE.

Britski, H.A.; Sato, Y. \& Rosa, A.B.S. 1984. Manual de identificação de peixes da região de Três Marias: com chave de identificação para os peixes da bacia do São Francisco. Brasília, Câmara dos Deputados, Codevasf, Divisão de Piscicultura e Pesca.

Britzke, R.; Nielsen, D. \& Oliveira, C. 2016. Description of two new species of annual fises of Hypsolebias antenori species group (Cyprinodontiformes: Rivulidae), from Northeast Brazil. Zootaxa, 4114(2): 123-138.

Buckup, P.A.; Menezes, N.A. \& Ghazzi, M.S. 2007. Catálogo das Espécies de Peixes de Água Doce do Brasil. Rio de Janeiro, Museu Nacional.

Carpenter, K.E. 2002. The living marine resources of the Western Central Atlantic. Volume 3: Bony fishes part 2 (Opistognathidae to Molidae), sea turtles and marine mammals. Rome, Food and Agriculture Organization of the United Nations. (Species Identification Guide for Fishery Purposes and American Society of Ichthyologists and Herpetologists Special Publication, n. 5).

Costa, S.Y.L.; Viana, L.G.; Barbosa, J.E.L. \& Ramos, T.P.A. 2017. Composition of the ichthyofauna in Brazilian semiarid reservoirs. Biota Neotropica, 17(3): $1-11$.
Eschmeyer, W.N.; Fricke, R. \& van Der Laan, R. 2017. Catalog of fishes: genera, species, references. Available at: http://researcharchive.calacademy.org/ research/ichthyology/catalog/fishcatmain.asp. Access in: 08/07/2017.

Ferreira, F.R.F. 2011. De Papary à (Dio) Nísia: cidade e mulher. Imburana. Revista do núcleo Câmara Cascudo de estudos Norte-Rio-Grandenses, 2: 25-37.

Figueiredo, J.L. \& Menezes N.A. 1980. Manual de peixes marinhos do Brasil, Vol. III. Teleostei. São Paulo, Museu de Zoologia/Universidade de São Paulo. 90p.

Fowler, H.W. 1941. A collection of fresh-water fishes obtained in eastern Brazil by Dr. Rodolpho von Ihering. Proceedings of the Academy of Natural Sciences Philadelphia, 93: 123-336.

Gurgel-Lourenço, R.C.; Sousa, W.A.; Sánchez-Botero, J.I. \& Garcez, D.S. 2013. Ichthyofauna of two reservoirs in the middle Acaraú River basin, Ceará, Northeastern Brazil. Check List, 9(6): 1391-1395.

Instituto Brasileiro de Geografia e Estatística (IBGE). 1990. Divisão Regional do Brasil em Mesorregiões e Microrregiões Geográficas. Rio de Janeiro, Fundação Instituto Brasileiro de Geografia e Estatística - IBGE. v. 1.

Jenkins, O.P. \& Branner, J.C. 1913. Geology of the Region about Natal, Rio Grande do Norte, Brazil. Proceedings of the American Philosophical Society, Philadelphia, 52(211): 431-466.

Jerep, F.C. \& Malabarba, L.R. 2014. A new species of Serrapinnus Malabarba, 1998 (Characidae: Cheirodontinae) from Rio Grande do Norte State, northeastern Brazil. Neotropical Ichthyology, 12(2): 301-308.

Kullander, S.0. 1983. A revision of the South American cichlid genus Cichlasoma (Teleostei: (ichlidae). Stockholm, Swedish Museum of Natural History.

Langeani, F.; Buckup, P.A.; Malabarba, L.R.; PY-Daniel, L.H.R.; Lucena, C.A.; Rosa, R.S.; Zuanon, J.A.S.; Lucena, Z.M.S.; Britto M.R.; Oyakawa 0.T. \& Gomes-Filho, G. 2009. Peixes de água doce. In: Rocha, R.M. \& Boeger, W.A.P. (Orgs.). Estado da arte e perspectivas para a zoologia no Brasil. Curitiba, Editora da Universidade Federal do Paraná. p. 211-230.

Leão, T.C.C.; Almeida, W.R.; Dechoum, M.S. \& Ziller, S.R. 2011. Espécies exóticas invasoras no Nordeste do Brasil: contextualização, manejo e políticas públicas. Recife, Centro de Pesquisas Ambientais do Nordeste e Instituto Hórus de Desenvolvimento e Conservação Ambiental.

Lévêque, C., Oberdorff, T., Paugy, D., Stiassny, M.L.J. \& Tedesco, P.A. 2008. Global diversity of fish (Pisces) in freshwater. Hydrobiologia, 595(1): 545-567.

Lima, S.M.Q.; Ramos, T.P.A.; da Silva, M.J. \& Rosa, R.S. 2017. Diversity, distribution, and conservation of the Caatinga fishes: advances and challenges. In: Silva, J.M.C.; Leal, I.R.; Tabarelli, M. (Orgs.). Caatinga the largest tropical dry forest region in South America. Springer. p. 97-131. Disponível em: https://link.springer.com/chapt er/10.1007/978-3-319-68339-3 4

Lira, M.G.S.; Paiva, R.E.C.; Ramos, T.P.A. \& Lima, S.M.Q. 2015. First record of Kryptolebias hermaphroditus Costa, 2011 (Cyprinodontiformes: Rivulidae) in the extreme north Atlantic Forest mangroves, Rio Grande do Norte state, Brazil. Check List, 11(3): 1656.

Lucena, C.A.S.; Calegari, B.B.; Pereira, E.H.L. \& Dallegrave, E. 2013. 0 uso de óleo de cravo na eutanásia de peixes. Boletim Sociedade Brasileira de Ictiologia, 105: 20-24.

Malabarba, L.R. \& Reis, R.E. 1987. Peixes. In: Manual de técnicas para a preparação de coleções zoológicas, n. 36. Campinas, Sociedade Brasileira de Zoologia.

Marceniuk, A.P. 2005. Chave para identificação das espécies de bagres marinhos (Siluriformes, Ariidae) da costa brasileira. Boletim do Instituto de Pesca, 31(2): 89-101.

Ministério do Meio Ambiente (MMA). 2014. Portaria № 445, de 17 de Dezembro de 2014. Lista Nacional Oficial de Espécies da Fauna Ameaçadas de Extinção - Peixes e Invertebrados Aquáticos. Diário Oficial da União, Brasília. 
Myers, G.S. 1949. Salt-tolerance of fresh-water fish groups in relation to zoogeographical problems Bijdragen tot de Dierkunde, 28: 315-322.

Novaes, J.L.C.; Moreira, S.I.L.; Freire, C.E.C.; Sousa, M.M.O. \& Costa, R.S. 2013. Fish assemblage in a semi-arid Neotropical reservoir: composition, structure and patterns of diversity and abundance. Brazilian Journal of Biology, 74(2): 290-301.

Paiva, R.E.C.; Lima, S.M.Q.; Ramos, T.P.A. \& Figueiredo, L.M. 2014. Fish fauna of Pratagi River coastal microbasin, extreme north Atlantic Forest, Rio Grande do Norte state, northeastern Brazil. Check List, 10(5): 968-975.

Ploeg, A. 1991. Revision of the South American cichlid genus Crenicichla Heckel, 1840, with descriptions of fifteen new species and considerations on species groups, phylogeny and biogeography (Pisces, Perciformes, (ichlidae). Amsterdam, Academisch Proefschrift, Universiteit van Amsterdam. 152p.

Ramos, T.P.A.; Barros-Neto, L.F.; Britski, H.A. \& Lima, S.M.Q. 2013. Parotocinclus seridoensis, a new hypoptopomatine catfish (Siluriformes: Loricariidae) from the upper rio Piranhas-Açu basin, northeastern Brazil. Neotropical Ichthyology, 11(4): 787-796.

Ramos, T.P.A.; Lehmann A.P.; Barros-Neto, L.F. \& Lima, S.M.Q. 2016. Redescription of the endangered hypoptopomatine catfish Parotocinclus spilurus (Fowler, 1941) (Siluriformes: Loricariidae) from the upper rio Jaguaribe basin, northeastern Brazil. Neotropical Ichthyology, 14(1): e150098.

Ramos, T.P.A; Zawadzki, C.H.; Ramos, R.T.C. \& Britski, H.A. 2017. Redescription of Hypostomus johnii, a senior synonym of Hypostomus eptingi (Siluriformes: Loricariidae), Northeastern Brazil. Neotropical Ichthyology, 15(2): e160064.

Rodrigues-Filho, C.A.S.; Gurgel-Lourenço, R.C.; Bezerra, L.A.V.; Sousa, W.A.; Garcez, D.S.; Lima, S.M.Q.; Ramos, T.P.A. \& Sánchez-Botero, J.I. 2016. Ichthyofauna of the humid forest enclaves in the tablelands of Ibiapaba and Araripe, Northeastern Brazil. Biota Neotropica, 16(4): e20160273.

Rosa, R.S., Menezes, N.A., Britski, H.A., Costa, W.J.E.M. \& Groth, F. 2003. Diversidade, padrões de distribuição e conservação dos peixes da Caatinga. In: Leal, I.R.; Tabareli, M. \& Silva, J.M.C. (Eds.). Ecologia e Conservação da Caatinga. Recife, Editora da Universidade Federal de Pernambuco. p. 135-180.

Sabino, J. 1999. Comportamento de peixes em riachos: métodos de estudo para uma abordagem naturalística. In: Caramaschi, E.P.; Mazzoni, R.; Bizerril, C.R.S.F. \& Peres-Neto, P.R. (Eds.). Oecologia Brasiliensis. Rio de Janeiro. p. 183-208.
Santos, M.C.F. 2005. A prática da carcinicultura de Litopenaeus vannamei (Boone, 1931) (Crustacea, Decapoda, Penaeidae) e suas implicações no Nordeste do Brasil. Boletim Técnico Científico do (EPENE, 13: 129-142.

Santos, M.C.F. \& Coelho, P.A. 2002. Espécies exóticas de camarões Peneídeos (Penaeus monodon Fabricius, 1798 e Litopenaeus vannamei Boone, 1931) nos ambientes estuarino e marinho do Nordeste do Brasil. Boletim Técnico Científico do CEPENE, 10: 207-220.

Secretaria de Recursos Hídricos do Estado do Rio Grande do Norte (SERHID). 2001. Plano estadual de recursos hídricos, Bacia 10 - Trairí. Available at: http://adcon.rn.gov.br/ACERVO/IGARN/DOC/DOC00000028905. Access in: 11/05/2015.

Silva, M.J.; Neves, C.P.; Ramos, T.P.A.; Pinto, M.P. \& Lima, S.M.Q. 2017. Efetividade das unidades de conservação para a ictiofauna das bacias hidrográficas envolvidas na transposição do rio São Francisco. In: Mantovani, W.; Monteiro, R.F.; Anjos, L. dos \& Cariello, M. (Orgs.). Pesquisas em unidades de conservação no domínio da Caatinga: subsídios à gestão. Fortaleza, Editora da Universidade Federal do Ceará. p. 181-205.

Silva, M.J.; Ramos, T.P.A.; Diniz, V.D.; Ramos, R.T.C. \& Medeiros, E.S.F. 2014. Ichthyofauna of Seridó/Borborema: a semi-arid region of Brazil. Biota Neotropica, 14(3): 1-6.

Slobodian, V.B. 2018. Taxonomic revision of Pimelodella Eigenmann \& Eigenmann, 1888 (Siluriformes: Heptapteridae): an integrative proposal to delimit species using a multidisciplinary strategy. (Doctoral Thesis). São Paulo, Museu de Zoologia, Universidade de São Paulo.

Starks, E.C. 1913. The fishes of the Stanford Expedition to Brazil. Stanford, Leland Stanford Junior University Publications. 77p.

Teixeira, F.K.; Ramos, T.P.A.; Paiva, R.E.C.; Távora, M.A.; Lima, S.M.Q. \& Rezende, C.F. 2017. Ichthyofauna of Mundaú river basin, Ceará State, Northeastern, Brazil. Biota Neotropica, 17(1): e20160174.

Uieda, V.S. \& Castro, R.M.C. 1999. Coleta e fixação de peixes de riachos. In: Caramaschi, E.P.; Mazzoni, R.; Bizerril, C.R.S.F. \& Peres-Neto, P.R. (Eds.). Oecologia Brasiliensis Ecologia de Peixes de Riachos. Rio de Janeiro, UFRJ/ PPGE. p. 1-22. (Série Oecologia Brasiliensis, v. 6)

Vari, R.P. 1989. Systematics of the neotropical characiform genus Psectrogaster Eigenmann and Eigenmann (Pisces: Characiformes). Smithsonian Contributions to Zoology, 481: 21-23.

Zawadzki, C.H.; Ramos, T.P.A. \& Sabaj, M. 2017. Hypostomus sertanejo (Siluriformes: Loricariidae), new armoured catfish species from northeastern Brazil. Journal of Fish Biology, 91: 317-330. 